\title{
Pre-Contractual Disclosure as a Cornerstone of the New Saudi Commercial Franchise Legislation
}

\author{
Rakan F. Alrdaan \\ Law School, University of Tabuk, Tabuk, Saudi Arabia \\ Email:r.alrdaan@ut.edu.sa
}

How to cite this paper: Alrdaan, R. F. (2021). Pre-Contractual Disclosure as a Cornerstone of the New Saudi Commercial Franchise Legislation. Beijing Law Review, 12, 228-249.

https://doi.org/10.4236/blr.2021.121014

Received: February 17, 2021

Accepted: March 28, 2021

Published: March 31, 2021

Copyright $\odot 2021$ by author(s) and Scientific Research Publishing Inc. This work is licensed under the Creative Commons Attribution International License (CC BY 4.0).

http://creativecommons.org/licenses/by/4.0/

(c) (i) Open Access

\begin{abstract}
A healthy franchise market needs a legal environment that regulates the orderly development of franchising for the benefit of all involved. The new Saudi Commercial Franchise Legislation (CFL) was introduced in October 2019, and came into force in April 2020, to promote transparency and disclosure of rights and obligations and to afford protection to all the contracting parties. One of the significant changes introduced by the CFL was the obligation of "pre-contractual disclosure". This article aims to explore and analyse the duty of franchise disclosure as introduced by the CFL, and will compare it best practices from other jurisdictions. The first part of this paper briefly introduces the franchise format, first defining it, and then giving an overview of the franchise regulation in Saudi Arabia. The second part will offer answers to the questions: what is meant exactly by franchise disclosure; why do we need pre-contractual disclosure; and is it alone sufficient to provide a healthy regulatory environment for franchising? In the third part, the key features of the obligation of disclosure, as imposed by the CFL, will be examined in depth.
\end{abstract}

\section{Keywords}

Franchise, Franchising, Law, Legislation, Saudi Arabia

\section{Introduction}

Franchising ${ }^{1}$ can most simply be understood as a business format for distributing goods and services. ${ }^{2}$ It has become one of the most successful and wide-

\footnotetext{
${ }^{1}$ Linguistically, the word "franchising" derived from the obsolete French term "franche" meaning "to free" or "to exempt". See (Blair \& Lafontaine, 2005: p. 14; Dicke 1992: p. 9-10). For some account of franchise history, see (Brown et al., 2014, Chap. 1; Luxenberg, 1985: p. 12-13).

${ }^{2}$ It is noteworthy that franchising is not an industry, rather, it is a method of business that has been employed in various industries. See (Emerson, 1990: p. 1507).
} 
spread business models, and is an increasingly popular one (Emerson, 2016: p. 103). Historically, the concept of the franchise first entered the Saudi market in late of 1970s (early 1980s), when a Saudi company (Binzaqer Co.) obtained a franchise license from two American companies (Wimby Restaurants and Martinizing Dry Cleaning) (The Economic Journal of the Eastern Chamber of Commerce in Saudi, 2017: p. 46). Today, the franchise market in Saudi Arabia is one of the fastest non-oil sectors as measured by growth, accelerating at an average of $27 \%$ annually. At the time of writing, the number of franchised units exceeds 15,000 units, either at local or international level. It is estimated that Saudi Arabia businesses have acquired around 50\% of the market value of franchises in the Middle East and North Africa, which is approximately worth U.S. 30 billion dollars (The Saudi Franchise Expo, 2020). These figures explain the significance of the franchise market today.

The increase in, and role played by, franchising in the Saudi economy has necessitated the establishment of a healthy regulatory environment. Almost four decades after the emergence of franchising in Saudi Arabia, long-awaited specific franchise legislation was introduced in October 2019. The Council of Ministers issued the Commercial Franchise Legislation (CFL), which came into force in April 2020, accompanied by Implementing Regulations (CFLIR). The purpose of the CFL is to encourage franchise activities in Saudi Arabia by introducing a regulatory framework, that promotes transparency in franchise transactions, ensuring protection for both franchisor and franchisee (The CFL, Art. 2). It addresses critical issues that arose in the former legislative vacuum, relating variously to the pre-contract phrase, such as the obligation of disclosure and registration, and to the on-going contract itself, such as transfer, contract renewal, and termination.

One of the more significant requirements, if not the principle requirement, introduced by the CFL is that of pre-contractual disclosure, which is imposed upon the franchisor. Franchise disclosure is a vital concern in the franchising context, to the extent that in many countries, the franchise statutes are essentially disclosure laws. The disclosure obligation requires franchisors to disclose to potential franchisees specific information that would highly affect the franchisee's decision about whether to invest. The aim of this article is to examine the requirement for disclosure as imposed under the Saudi CFL. Thus, the first part of this paper commences by introducing the nature of franchise: its definition and its regulation in Saudi Arabia. The second part answers relevant conceptual questions; i.e. what is exactly meant by franchise disclosure? Why do we need pre-sale disclosure? And, is disclosure sufficient in itself to provide a healthy regulatory environment for franchising? Finally, the obligation to make this disclosure as described in the CFL, will be discussed in the third part.

\section{Conceptual Framework of Franchise}

Prior to discussing franchise pre-sale disclosure as imposed under the CFL, it is 
crucial to define the concept of "franchise" and how it is regulated in Saudi Arabia. These two points are covered by the following discussion.

\subsection{Franchise Definition}

According to Art. 1 of the Saudi's CFL, a franchise is defined as:

The granting by a person called the franchisor to another person called the franchisee of the right to conduct business-subject of the franchising for its own account linked to the trademark or the trade name owned by the franchisor or licensed to it, providing technical expertise and know-how to the franchisee and determining the manner of operating the franchised business, in exchange for monetary or non-monetary consideration, excluding sums paid by the franchisee to the franchisor in exchange for goods or services. ${ }^{3}$

This definition is, broadly consistent with that set out in international practice. ${ }^{4}$ It encompasses the most significant elements of the concept of franchise (Pitegoff \& Garner, 1989: p. 188-194; Stanworth \& Curran, 1999: p. 327-329): 1) it involves the use of a trade name and trademark that the franchisee operates under; 2) the franchisor is to provide "significant assistance" to the franchisee, and the franchisor can exert "significant control" over the franchisee's method of operations, including but not limited to, training, business organisation, building design, location; and 3) the franchisee must pay, whether directly or indirectly, fees to the franchisor (Pitegoff \& Garner, 1989: p. 188).

Franchising businesses can be of various types (Hillstrom, 2017: p. 529). Among the more common forms is "business format franchising", under which, as the name suggests, the franchisee is required to adhere to certain operational standards adopting a complete specified business format, marketing plans, operations manuals, and distribution techniques. Examples of this form are found in the contexts of fast food, restaurants and hotels. The other main of franchise forms is "product distribution", which generally concerns the licensing of a product line by a franchisor to a franchisee (Hillstrom, 2017: p. 529). This type applies to businesses with greater total sales than business format franchising; ${ }^{5}$ for example, automobile dealerships and gasoline service stations..

\subsection{The Regulation of Franchising in Saudi Arabia}

Until October 2019 there was no specific legislation governing franchising op-

${ }^{3}$ Compare this definition with that given by the International Franchise Association (IFA) stating: "[A] method of distributing products or services. At least two levels of people are involved in a franchise system: 1) the franchisor, who lends his trademark or trade name and a business system; and 2) the franchisee, who pays a royalty and often an initial fee for the right to do business under the franchisor's name and system."

${ }^{4}$ See the definitions given by the European Franchise Federation (EFF), the Federation Française de la Franchise (FFF) and the International Institute for the Unification of Private Law (UNIDROIT). ${ }^{5}$ In some instances the franchisee may even have a role in production, this can be seen with many soft drink bottlers. 
erations in Saudi Arabia. ${ }^{6}$ Instead, franchising, along with other types of transactions, was legally governed by the Commercial Agency Law (CAL) enacted in 1962. The CAL when first promulgated was intended to regulate agency contracts only, ${ }^{7}$ as the concept of franchising was not a significant pillar of the economy, if not entirely unknown. Thirty years later, in 1992, franchising and other commercial transactions, ${ }^{8}$ were officially brought under the umbrella of the CAL by ministerial decision in 22 March 1992. Thus, since this time, CAL has been the governing legislation for the franchise sector in Saudi Arabia.

However, in reality this did not place franchises on a solid legal foundation, as the CAL is inefficient when applied to franchising for a number of reasons. Firstly, the nature of the provisions of CAL clearly demonstrate that it was designed to regulate commercial agent contracts only, and no other types of commercial contracts. This is apparent from the provisions set out in CAL. Indeed, although there are some similarities between commercial agencies and franchise contracts, they are fundamentally different in nature, ${ }^{9}$ with the result that applying CAL to franchise contracts is a flawed approach. The second reason is that the CAL is a procedural law and not substantive by nature. ${ }^{10}$ It regulates the practice of the agency's profession in Saudi Arabia; for example, the requirement that the agent be a Saudi national, the obligation to register and publicise the agency, and that it does not regulate the contractual relationship between parties. ${ }^{11}$ For the aforementioned reasons, the application of the CAL on franchise contracts was inadequate, and unhelpful to franchisors and franchisees wishing to trade in a healthy regulatory environment.

In October 2019, the Council of Ministers promulgated Commercial Franchise Legislation, which came into force in April 2020 with associated Implementing Regulations (CFLIR). The CFL, as the first legislation specializing in the franchise sector, aims to govern franchise contracts in a comprehensive manner in accordance with international best practices. The objective of the CFL is to encourage commercial franchise activities in Saudi Arabia by introducing a regulatory framework, and to promote the principle of transparency in franchise transactions, in order to provide essential protection to the franchisor and franchisee (The CFL, Art. 2). It addresses critical issues that were suffering from being in a legislative vacuum, whether issues that arose in the pre-contract context, such as, the obligation of disclosure and registration, or issues arise during the

\footnotetext{
${ }^{6}$ Nor there was any franchise association that might create a legal framework or self-regulating code for its members as in other countries such as, the British Franchise Association (BFA) and the Egyptian Franchise Development Association (EFDA).

${ }^{7}$ It is limited in its application to contracts in agency only, and not to other commercial agencies such as commission agencies and commercial representatives. This is inferred from the CAL and its IRCAL provisions, which mainly legislate agency in contracts. (Alghamdi, 2015: p. 285-286).

${ }^{8}$ These are: service agencies, franchise contracts, agents for national projects, and sub-distributors.

${ }^{9}$ In summary, the agency contract does not involve the routine use of trademarks, and does not involve one party being subject to training or control. (Sherman, 2003: p. 349-350).

${ }^{10}$ This is opposite to some neighbouring countries' laws, which regulate the contractual relationship, such as the Kuwaiti Commercial Law 1980 and the Egyptian Commercial Law 1999.

${ }^{11}$ Consequently, the CAL has been heavily criticised. (Al-Jabar, 1997: p. 113).
} 
on-going contract, such as, transfer, contract renewal, and termination.

It is vital to point out here there are other laws alongside the CFL that govern certain aspects of franchise transactions, these are: 1) the Commercial Trademarks Law, as it has been clarified in the definition of franchises that the trademark constitutes a significant element, and this law is concerned with matters of licensing and protection;12 and 2) the Law of Patents, Layout Designs of Integrated Circuits, Plant Varieties, and Industrial Designs, which governs the franchisee's license to exploit patents owned by the franchisor.

\section{Franchise Disclosure in Principle}

Before investigating franchise disclosure as a legal requirement and discussing how Saudi legislature approaches it, it would be beneficial to examine the legislative forms of franchise legislation around the world, to obtain a clearer understanding of the following discussion. Today, 39 countries have franchise-specific laws. ${ }^{13}$ However, they each vary in their approaches to the laws adopted, generally focusing on two approaches (Germann \& Christie, 2010: p. 12-13). The first approach is to regulate only the pre-contractual stage covering issues such as disclosure and registration requirements" (sometimes known as "franchise pre-contractual law", "pre-contractual disclosure law" and "franchise disclosure law") (Forgas, 2017: p. 23-25). The second approach is to regulate the franchisor-franchisee relationship during the on-going contract stage in addition to the pre-contractual franchise, ${ }^{15}$ prescribing the right to transfer, renewal, termination, compensation and other items (known as "franchise relationship law") (Pitegoff \& Garner, 1989: p. 45), thereby comprising comprehensive franchise legislation.

The following discussion will answer the questions: what is exactly meant by franchise disclosure? Why do we need pre-contractual disclosure? And, is pre-contractual disclosure sufficient in itself to provide a healthy regulatory en-

\footnotetext{
${ }^{12}$ It has been stated that a trademark is the cornerstone of the franchise concept. See Susser v. Carvel Corp., 1962. See also, (Lagarias \& Kushell, 2013: p. 4) (considering that the trademark is the "core" of the franchise agreements).

${ }^{13}$ They are: seven in the Americas, fifteen in Europe, three in Africa, five in Central and Western Asia, six in East and Southeast Asia, and three in the South Pacific. In some countries franchise-specific laws are not pure franchise law, rather they are linked to foreign trade or investment laws, as in China (Measures for the Administration of Commercial Franchise) and Korea (Fair Franchise Transactions Law, 2002), or linked to anti-trust laws as in Japan (Japan Fair Trade Commission Guidelines, 2002) and Venezuela (Pro-Competition Agency's Guidelines for the Evaluation of Franchise Agreements, 2000). (Emerson, 2016: p. 599; Abell, 2011a). However, countries such as the U.S., Germany, New Zealand and all the Arabic countries are examples of majority countries that do not have franchise specific laws.

${ }^{14}$ For example, U.S. (at the federal level, franchising is regulated by the Federal Trade Commission and are commonly known as the "FTC Rule" 2007. The FTC Rule requires pre-sale disclosure. See also, NUIDROIT; France (in France the franchise disclosure is regulated under Art. L330-3 of the French Commercial Code 1989 (known as "The Loi Doubin". The Lio Doubin applies to any person who provides to another person a corporate name, trademark, or trade name in furtherance of a business arrangement with an "exclusive or quasi-exclusive territory.")

${ }^{15}$ For example, Malaysia (Franchise Act 1998); some U.S. states such as New Jersey (Franchise Practices Act) and Wisconsin (Franchise Investment Law); and recently Saudi Arabia.
} 
vironment for franchising?.

\subsection{What Is Franchise Disclosure?}

Pre-contractual disclosure is the most important area to legislate in the context of franchising, such that in some countries franchise legislation is nothing more than disclosure legislation (Campbell \& Netzer, 2008: p. 288). Significantly, 90 per cent of franchisors-franchisees disputes globally involve allegations of the disclosure of incorrect information, or non-disclosure of material information (Peters, 2004: p. 34).

Franchise disclosure is a legal principle by which the franchisor is required to provide the prospective franchisee with specific material information concerning the franchise to inform the franchisee's decision about whether to invest. The information disclosed should be accurate, timely, up-to-date, verified and comprehensive, also including the franchisor's existing and former franchisees, affiliates, franchise business, franchise contracts, monetary aspects, and other relevant information.

Notably, the innovation of franchise disclosure is attributed to the U.S., and all countries that require franchise disclosure are heavily influenced by the U.S. FDD (Abell, 2011a: p. 10; Gandhi, 2014: p. 3-4).

\subsection{Why Do We Need Franchise Disclosure?}

The nature of franchise contracts reveals the potential for the franchisor misguide to the franchisee (Statement of Basic and Purpose, 1978, at 59623-59639). The major cause of misconduct and abuses is the imbalance of power between the franchisor and franchisee (Bresler's 33 Flavors Franchising Corp. v. Wokosi; Designs in Medicine, Ic. V. Xomed, Inc; Shell Oil Company v. Marinello). The nature of this imbalance is an informational one arising prior the sale of the franchise (Statement of Basis and Purpose, 1978, at 59625). Before selling a franchise business, the franchisor invites the prospective franchisee to join a pre-existing system. At this stage, information regarding the franchise business, such as the history of the business, its nature, and its potential profitability resides exclusively with the franchisor.

Unfortunately, many opportunistic franchisors have availed themselves of this informational imbalance by making detailed non-disclosures or misrepresentations as a way of inducing the sale of their franchise business (Statement of Basis and Purpose, 1978, at 59627-59639). Franchisees are often unaware of the results of such conduct until they have engaged with and invested large amounts of effort and capital in their business (Pruitt, 1985: p. 565). Therefore, franchisors' non-disclosures and misrepresentations during the pre-sale of the franchise are a recurrent issue demanding legislation.

In Saudi Arabia, despite the existence of the practice of franchising for nearly

${ }^{16}$ This is the position in all Arabic countries. (Young, 2011: p. 10).

${ }^{17}$ For a full account of Islamic law see for example, (Burns, 2013; Vogel, 2000). 
four decades prior to the introduction of the CFL, there was no legislative provision mandating the requirement of disclosure, whether under CAL or any other relevant law. ${ }^{16}$ However, under Shari'ah law (Islamic law), ${ }^{17}$ the general law governing contract in Saudi Arabia, ${ }^{18}$ both contracting parties must tell the truth and provide no false information to one another under the principle of "good faith" (Alghamdi, 2015: p. 296-300). Based on this principle parties may seek judicial remedy in cases of non-disclosure or fraudulent disclosure. However, this legal basis is questionable in terms of its adequacy to provide sufficient protection for franchisees. This is due to the ambiguity present in much of the information to be revealed before the signing of a contract; i.e. concerning the time to be provided, the way it is to be delivered and so on. Under normal conditions the parties to a contract provide the information necessary to execute the contract according to its natural meaning, but in franchise contracts the information disclosed is different in nature, quantity, timing and delivery. Moreover, it by necessity extends further than other contracts, covering information about the business network, bankruptcy history, criminal history among other things. What demonstrates its unique nature is the fact that the franchise law in many countries is essentially a disclosure law only. Therefore, the existence of a law that explicitly clarifies what information must be disclosed, its quantity, in addition to how and when, was necessary to effectively regulate the franchise sector in Saudi Arabia.

\subsection{Is Disclosure Sufficient to Protect the Franchisee?}

The franchising landscape is and has been the setting for controversy and debate regarding the sufficiency of a disclosure obligation alone to create a healthy franchise environment (Horwitz \& Volpi, 1980: p 224-226). It has been argued that disclosure alone affords the franchisee sufficient protection, and that franchisees do not need any more protection against franchisors' abuses under "franchise relationship law" (Brickley et al., 1991: p 109-110; Horwitz \& Volpi, 1980: p. 276-78; Killion, 2008: p. 31; Ribstein, 1993: p. 279-281). It is assumed that potential franchisees are sophisticated business people (Killion, 2008: p. 30), and that being so, that they would consider all the relevant disclosed information before concluding any franchise contract and make a well-informed choice among the available franchise contracts. The disclosed information is intended to warn prospective franchisees against potential abuses by the franchisor, including data on pending and prior lawsuits involving the franchisor.

Furthermore, it is believed that franchise relationship law is a form of overregulation that disrupts the contractual allocation of power inherent in franchise contracts (Horwitz \& Volpi, 1980: p. 217; Pruitt, 1985: p. 568-569). It disturbs

\footnotetext{
${ }^{18}$ The legal system of Saudi Arabia is primarily based on Islamic law. It is explicitly stated in Art. 47 of the Basic Law of Governance (represent the constitutional law): "The courts will apply the rules of the Islamic Shari'ah in the cases that are brought before them, in accordance with what is indicated in the Book and the Sunnah, and statutes decreed by the Ruler which do not contradict the Book or the Sunnah." See also Art. 7.
} 
the bargain struck between the contracting parties by restricting and hampering the ability of franchisors to protect the goodwill associated with their franchise trademarks, as it imposes significant limitations on their contractual control (Pruitt, 1985: p. 570). This has led many countries to limit their franchise regulations to disclosure laws only, the U.S. being the clearest example.

Conversely, it has been asserted that there remain inherent limitations affecting the use of disclosure to deter franchisor misconduct during the franchise relationship, and that on that basis relationship law is important to consider side by side with disclosure law (Hadfield, 1990: p. 944; Spencer, 2009: p. 34; Emerson, 2012: p. 204). The protection provided to franchisees under the prescription of disclosure exists as long as the franchisor is selling a franchise business. Relationship law extends beyond disclosure regulating the continuing relationship between franchisors and franchisees after conclusion of the agreement. Thus, typical relationship laws address those areas that are of critical importance to franchisees; such as, the duty of good faith, franchise transfers, nonrenewal and unjust termination.

Relationship law provides additional contractual protection by seeking to level the playing field between contracting parties, who are frequently presented with a standard form of franchise contract on a take-it-or-leave-it basis. ${ }^{19}$ In most instances, franchise contracts are drafted by franchisors and so seldom reflect the interest and concerns of the franchisees (Lagarias \& Kushell, 2013: p. 4). As one commentator elucidates: "most franchise agreements are drafted by a franchisor's lawyers to benefit the franchisor in every possible way and are usually presented to franchisees on a take-it-or-leave-it basis." (Lagarias \& Boulter, 2010: p. 1 ). When the law covers disclosure point only, broadly drafted termination terms might ultimately allow a franchisor to terminate a contract at will (Pruitt, 1985: p. 565). Given this opportunity, many franchisors have ended contracts for improper causes, such as to finalize a personal dispute with a franchisee (Seaway Yachts, Inc. v. Brunswick Corp), or to reacquire a profitable outlet before the contract term has ended (Neptune T.V. \& App. v. Litton Microwave).

Assuming that franchisees consider all the relevant information before entering into a franchise contract is not necessary reasonable. New franchisees joining franchise networks frequently lack prior business ownership experience, ${ }^{20}$ and this lack of experience heightens the risk to these prospective franchisees when attempting to consider all of the relevant details concerning the ownership of a franchise unit (Hadfield 1990, p. 961-962; Spencer, 2009: 35-36. For empirical studies, see Morrison, 1996: p. 28-30; Peterson \& Dant, 1990: p. 50-51).

Thus, relationship law can be beneficial by providing additional contractual protection to the weak party in the franchise contract, that is franchisee. This

\footnotetext{
${ }^{19}$ Some U.S. courts have found that franchise contracts are typically one-sided "adhesion contract" written by franchisor. See for example (Kubis \& Perszyk Assocs. Inc. v. Sun Microsys; Ticknor v. Choice Hotels Int' I).

${ }^{20}$ The main reason for this phenomenon refers to the nature of the franchise business format, which attracts individuals with limited business ownership experience who are seeking to invest in an already successful and established business system. See (Watson \& Stanworth, 2006: p. 340).
} 
protection extends beyond the pre-contractual stage to cover the continuing relationship of between franchisors and franchisees after execution of the agreement, by regulating critical contractual areas, such as the duty of good faith, franchise transfers, no renewal right and unjust termination. Indeed, relationship law can become negative factor if, and only if, overregulation interferes with the relationship between the parties to the extent that it disrupts that relationship. The Saudi CFL is a comprehensive law, that regulates disclosure requirements as well as the on-going relationship between parties. Therefore, it effectively provides the franchisee with legislative protection prior to and after the franchise agreement. This is explicitly stated by the CFL as it aims to enhance the principle of transparency and achieve the necessary protection without prejudicing the principle of contractual freedom (The CFL, Art. 2).

\section{Franchise Disclosure in the Saudi CFL}

The obligation of pre-contractual disclosure, as introduced in the recent Saudi CFL, was to provide a layer of legal protection for the franchisee. The CFL deals clearly with the disclosure compliance obligations and directs who must provide disclosure documents; who must furnish them to prospective franchisees; how franchisees receive the disclosed documents; how long franchisees must have to review and read the disclosure information; and what the consequences of non-compliance would be. The following discussion will deal with the most important aspects relating to the duty of disclosure in reference to other jurisdictions for a better understanding of Saudi CFL.

\subsection{Information to Be Disclosed}

According to Art. 7 of the CFL, the franchisor is required to provide potential franchisees with a written disclosure document and a copy of the franchise agreement prior to signing, and this disclosure must contain details of the following 17 items:

1) Cover page; title; providing general information such as the name and date;

2) List of items included in the disclosure and their page numbers;

3) Full details of the sub-franchisor and its group-if the franchise business was granted by him;

4) The experience of the franchisor over the previous 5 years;

5) Full details of the franchisor;

6) Description of any judicial or arbitral dispute concerning the franchising business, whether pending or in the preceding five years;

7) Bankruptcy information about the franchisor or his group members over the previous 10 years;

8) The initial and on-going fees payable by the franchisee to the franchisor;

9) Total estimated initial investment for the start-up of a franchise operation;

10) The territory restriction and exclusivity of the franchise;

11) Information concerning the "location" in which the franchise business 
operates;

12) List of franchisees, with detailed addresses, for the last 3 years.

13) Financial statements of the franchisor;

14) The rights concerning use of "intellectual property";

15) The supply of goods and service;

16) The rights and obligations related to "marketing and advertisements"; and

17) The parties rights and obligations concerning expiry or termination of the franchise agreement;

These 17 items are in general common to any franchise disclosure law (see (Appendix 1; Abell, 2011a: p. 9). Despite the list's general consistency with the international practices, there are some variations in terms of the scope, whether in the required items or in the intensity of details required under each item. For example, in Australia, the franchisor is required, under the disclosure document, to provide approximately 250 information listed under 23 items (the Australian Franchising Code of Conduct (ACCC), Clause 6), UNIDROIT Model Franchise Disclosure Law provides for 28 items (UNIDROIT, Art. 6) and the U.S. FTC for 21 items (FTC Rule, 16 C.F.R. $\$ 436$ ).

On occasion, some information disclosed plays a significant role in the decision made by the prospective franchisee about whether to invest, the imposition of which is a matter of controversy in many jurisdictions. This can be exemplified by what is referred to as "earning claims" or "financial performance representation" (Cahn \& Woods, 2001: p. 122-131). Under this requirement the franchisor discloses information to the prospective franchisee to allow him to predict the potential earnings or revenue that can be generated from the franchise business (the Commentary on the Provisions of the UNIDROIT, Comment 108). Under the CFL meeting this requirement is a matter of the franchisor's choice (The CFL, Art. 7(3)). This correlates with the application of the law in many jurisdictions, where the requirement is optional (see Appendix 1). It is true that the information provided under this item is vital to the franchisee's decision to invest, as one commentator states: "there is nothing more relevant or influential to prospective franchisees when choosing a franchise than historical and expected franchise performance." (Eydt, 2013: p. 241). However, making such information available is a difficult task as is must be based on reliable and relevant empirical data, with any estimates clearly identified. Therefore, few, if any, franchisors are likely to possess sufficiently reliable information to provide this data. As a consequence, almost jurisdictions have rejected the mandatory earning claims requirement and left level of disclosure to the franchisor (Wulff, 2005: p. 327).

One of the requirements frequently listed in franchise disclosure laws (see Appendix 1), and not under the CFL describes "on-going relationship terms". Under this item, the franchisor is obliged to disclose information about multiple issues mainly; renewal, termination, transfer, and dispute resolution. In this way, a franchisee can be informed about when and whether his franchise can be renewed or terminated, and what his rights and the associated restrictions are 
when he disagree with the franchisor (see IFA website). This item is not required by the CFL, with the exception of some information concerning any possible entitlement to compensation and option to purchase any unsold stock upon termination of the franchise contract (Item 17 of the disclosure requirement under the CFL). Indeed, this is surprising due to the value of this information, although it must be a part of the content of the franchise agreement set out by CFLIR (The CFLIR, Art. 8). Thus, instead of being listed as an item for disclosure it is a mandatory clause in a franchise agreement.

It appears that the Saudi legislator is cautious about demanding specific information known to have caused controversy elsewhere. In particular, the requirement that information be provided concerning any criminal records of the franchisor or its legal representative (Peters, 2015: p. 97-100). It is believed that this information may contravene the law of privacy, and the opinion that an individual with a record should be given a second chance (Peters, 2004: p. 51). In addition, even if it were possible to require a franchisor to furnish such details about himself, it would not be possible to require him to do so about other person, as this might place him under liability (Peters, 2015: p. 99). Arguably, such information is important for a potential franchisee, as without it he might not be able to judge how honest and reliable the franchisor is, and in many countries such information is already in the public domain (Peters, 2004: p. 51). According to the CFL, as in other laws, such as in Australia (Item 4 of the disclosure requirement under the ACCC) and UNIDROIT (The UNIDROIT, Art. 7(G)), this information is required in fairly detailed form; being relevant to the franchise business and limited to the last five years (Item 6 of the disclosure requirement under the CFL). This is unlike the position in U.S., for example, where the information requested under this requirement is very detailed; covering any convictions pertaining to the franchisor or his legal representative in the preceding ten years (Item 3 of the disclosure requirement under the FTC Rule).

It is inappropriate to demand the disclosure of information that would not be of significant benefit to the franchisee, where it may constitute a hazard or place a great burden on the franchisor, that ultimately may lead to the latter's reluctance to franchise his business. For example, the disclosure of the franchisor's relevant know-how; as to do so, would compromise the franchisor's trade secrets. Also, it is not appropriate to require the franchisor to provide details about the market condition "market analysis". ${ }^{21}$ This would then remove from the franchisee the responsibility for his own business decisions, and thus encourage an unsuitable individual and nurture a blame culture (Abell, Ph.D. Dissertation 2011b: p. 285). These requirements were not part of the disclosure under the CFL, and are not present in the majority of franchise legislations (see Appendix 1).

\subsection{The Accuracy of Disclosure Documents}

It is not enough that a franchisor furnishes a potential franchisee with disclosure

${ }^{21}$ In France the franchisor is required to give a presentation on the state and development perspective of the relevant market. The Loi Doubin, Art. R.330-1. 
documents, but the documents must be accurate. The CFL explicitly affirms that any disclosure must be clear and accurate (The CFL, Art. 7.(2)). However, it seems that the requirement that disclosure information be literally accurate is not an easy task:

[A]s anyone who has drafted a [franchise disclosure] can testify, there is no certainty as to the nature of the information that has to be included in the various disclosure sections ... and reasonable person often differ in good

faith as to what has to be disclosed. (FTC Staff Report Baer, NPR 11, at 10)

This matter is addressed in the CFL. According to the CFL, the franchisee is entitled to rescind the contract and to be compensated (The CFL, Art. 17) in the event of a "material" breach of the franchisor's disclosure obligation. Furthermore, the franchisor is obliged to provide the franchisee with newly updated franchise documents in the event of any "material" change (The CFLIR, Art. 6.(2)). What constitutes "material" in the eyes of the CFL relates to when the disclosed information has a significant effect on the value of the franchise business, or the franchisee's decision to enter into the franchise agreement (The CFLIR, Art. 6.(2)). Materiality is thus the benchmark. It is inferred from the above that it would be immaterial if the inaccuracy has not affected to the value of the franchise business or the franchisee's decision about whether to invest.

In the context of accuracy, the CFL imposes on the franchisor an obligation to ensure information provided is up-to-date. specifically, the CFL indicates that, in the case of any material change in information related to the franchise after delivery to the prospective franchisee, the franchisor must deliver to the franchisee a new document or a separate document indicating material changes as soon as possible prior to the franchisee signing the contract or making any payment related to the franchise, whichever is earlier (The CFLIR, Art. 6.(2)). This differs from other jurisdictions, where this updated disclosure requirement is mandatory only upon the potential franchisee's reasonable request (FTC Rule, 16 C.F.R. $\$ 436.9(\mathrm{f})$ ). Other jurisdictions impose mandatory updates on a regular basis; stating that a franchisor must provide updated information within, 4 (The ACCC, Clause 8.(6)) or 6 (FTC Rule, 16 C.F.R. $\$ 436.7$ ), months of the end of each financial year. Such a requirement is not part of the CFL, under which the obligation to update relates to the occurrence of a material change and is not required on a regular basis.

\subsection{Registration of Disclosure Documents}

Departing from the notion of "prevention is better than cure", some jurisdictions impose on the franchisor an obligation to register disclosure documents, among other documents, with a registration authority before the franchise can be offered to the prospective franchisee. This step is intended to ensure review and approval to guarantee the franchisor meets certain minimum levels in the provision of information. This is ultimately in the best interest of the prospective 
franchisee to inform the investment decision. In addition, this procedure could enable the franchisor to be certain that his disclosure document complies with the law.

The requirement for advanced registration applies in countries such as Malaysia (the Franchise Act, Section 6). With regard to the CFL, the approach taken corresponds with countries such as the U.S., ${ }^{22}$ UNIDROIT, France and China, ${ }^{23}$ wherein advanced registration is not legally imposed. nevertheless, the CFL requires registration after the franchise agreement has been concluded, i.e., the franchisor must register the disclosed information along with the signed contract with the Ministry of Commerce within ninety days of the date the agreement was signed (The CFLIR, Art. 3). This is apparently for the purpose of documentation and archiving, rather than for review and approval.

Although the imposition of advanced registration for reviewing may-if it is well implemented-maintain market confidence in franchising, on the other side creates substantial challenges for both the franchisor and the administrator running the registry. In terms of the franchisor, this might result in a delay, as a result of the regulator's desire to review the documents filed. This fact is witnessed in states that impose this requirement. In Malaysia, for example, the registration process can take up to six months, and in some U.S. states, where advanced registration is imposed, this sometimes takes up to thirty days (Peter 2015, p. 104-105). This might also discourage the franchisors to use franchising as part of their business growth strategy, as it will inevitably result in increased cost and bureaucracy, and caution concerning the liability of non-compliance, ${ }^{24}$ as such obstacles cannot be ignored. With regard to the administrator, this imposition creates a considerable administrative burden to authenticate the quality or substance of the documents lodged, and possibly incurs a substantial cost. In view of the aforementioned, the Saudi legislator was right to not impose the requirement for advanced registration as it is unwieldy and cost ineffective.

\subsection{Delivery of Disclosure Documents}

Due to the important role of disclosed information, the method of its delivery is vital. What is provided in this regard in the CFL is that: "The franchisor must provide the franchisee with a copy of the disclosure document.." (The CFL, Art. 7). Today, alongside face-to-face meetings there are a variety of means through which business can be conducted. With the variety of means of electronic communications (e-mail, password protected internet, CD-ROM and other) disclo-

\footnotetext{
${ }^{22}$ Although the FTC Rule does not impose a federal registration requirement, 15 states require registration of the disclosure document before to the offer of a franchise, these states include Hawaii, California, Illinois, Indiana, Maryland, Michigan, Minnesota, New York, North Dakota, Oregon, Rhode Island, South Dakota, Virginia, Washington and Wisconsin.

${ }^{23}$ In China, there is no requirement to register the franchise disclosure document with any governmental authority, whether prior the offering the franchise or after the singing of the franchise agreement. See (Jones \& Wulff, 2007: p. 60).

${ }^{24}$ In Malaysia, failure to register can cost in penalties between 5000 and 50,000 Ringgit and sometimes to the impressment. (the Franchise Act, Section 6).
} 
sure documents can be delivered to the prospective franchisee, although e-mails is likely to be the favoured option, owing to cost efficiency and ease of use (Fisher \& Mullin, 2000: p. 48). However, in light of the absence of any clarification in the CFL concerning what is considered sufficient delivery, a question arises, over whether or not electronic communication is sufficient as a legal mode of delivery. The answer is important to ensure the avoidance of any confusion over whether or not documents have been delivered.

In the U.S., for example, the FTC Rule is accurate with regard to what constitutes legal delivery. It expressly permits the franchisor from delivering documents in either paper or electronic form, including via faxes, e-mail, computer disk or CD-ROM among other means (FTC Rule, 16 C.F.R. \$436.2). Although the CFL does not provide a definition of what constitutes a legal delivery, one may conclude that the Saudi legislator meant not to define the term "delivery", that is to be general, so that any means of delivery, whether in paper or electronic form, amounts to legal delivery. Nevertheless, it would be appropriate if the Saudi legislator were to lay out a clear definition of what amounts to delivery to the potential franchisee. Such a definition is critical to prevent any probability of future disputes regarding delivery compliance.

In the context of the importance of delivery of disclosure documents, some countries laws impose a requirement on the franchisee to formally acknowledge receipt of the disclosure document. Such an obligation is applied in, for example, the U.S. Australia and China. Whereas, in the UNIDROIT an acknowledgement receipt is optional, being subject to the request of the franchisor (see Appendix 2). Although this requirement may give rise to the incorporation of detailed provisions as to how this must be effected if disclosure is provided electronically (Statement of Basis and Purpose at 15467 FTC FAQs Question 15), it also provides grounds for accuracy and stability. Therefore, it would be appropriate if the Saudi CFL were to add the requirement of acknowledgment of receipt of the disclosure document by an affirmative action on the part of the recipient to authenticate his identity and confirm receipt. This could be done, for example, with a handwritten signature, an electronic signature, password or a security code.

\subsection{Timing of Disclosure}

The timing of the disclosure of information is vital. It should allow time for the franchisee to absorb the materials at hand to determine whether it is in his best interest to pursue the franchise opportunity. However, the time should be reasonable, as too long a period might risk the information becoming out of date, unduly slowing down the commercial process. In general, the time set out in countries that have franchise legislation tends to range between 10 and 30 days prior to the execution of an agreement or payment of a fee.

In China, this meditation period is thirty days at most (the Information Disclosure Measures, Art. 21), in France it is twenty days (the Loi Doubin, Art. 
L330-3), and in Malaysia it is ten days (the Franchise Act, section 15(1)). Surprisingly, some countries offer no minimum period of time, and Japan is an example. The approach taken by the CFL is in line with the majority of franchise laws, as in U.S. (FTC Rule 16 C.F.R. $\$ 436.2(\mathrm{a})$ ), UNIDROIT (the UNIDROIT, Art. 3) and Australia (the ACCC, Clauses 9), which sets the period of time for disclosure at fourteen days (the CFL, Art. 7). In any case, the difference between the countries is not that great (except for Japan), with the period adopted by the majority being fourteen days. However, too lengthy a period would unduly slow down the commercial process.

\subsection{Cooling Off Period}

Some countries' franchise laws require, in addition to a meditation period between the serving of disclosure information and closure, an additional period, usually ranging from 5 to 30 days, during which the franchisee can terminate the agreement, called the "cooling-off” period (Sotos, 2012: p. 11; Abell, 2011a: p. 10-11). This cooling-off period is viewed as necessary protection allowing the franchisee to "back out" of an executed franchise agreement. Countries such as China, Australia and Malaysia provide a cooling-off period (see Appendix 2).

In Saudi Arabia, the CFL does not provide for any cooling-off period. Arguably, the CFL requirement that franchisors provide disclosure documents at least fourteen days prior to the potential franchisee making a payment to the franchisor or signing the franchise agreement, and the requirement to keep the franchisee updated in the event of any material change to the disclosure document, makes it reasonable to deny the franchisee any additional time to revise his decision. To allow a cooling-off period, may threaten the sanctity of the contract. Furthermore, it is doubtful whether the availability of a short window in which to exercise the right to withdraw can effectively protect a franchisee from being imperfectly informed, as any defect in the contractual object is likely to become apparent only much later. As a result many jurisdictions, not only the CFL, do not legislate for a cooling-off period such as, U.S., UNIDROIT and France.

\subsection{Protection of the Confidentiality of Disclosed Documents}

It is common under franchise law to give a franchisor the right to execute a confidentiality agreement with the franchisee prior to disclosing any information. Simply put, such an agreement compels the franchisee, and in some instances, his principals, associates, and employees, to maintain trade secrets, commercial information and confidentiality, both during and after the termination of the franchise relationship (Vanderbroek \& Turner, 2006: p. 195).

The issue of protection of confidentiality in some franchise laws is optional; that is, it is the franchisor's decision whether the prospective franchisee needs to sign a confidentiality agreement; Australia (the ACCC, Clause 14) is an example. Other countries, such as Malaysia, explicitly provide for the obligation of confidentiality within their franchise law (the Franchise Act, section 26). With regard 
to the position in Saudi Arabia, the CFL explicitly provides for the confidentiality and protection of information as a compulsory clause in the franchise agreement. It imposes a duty of confidentiality both upon the franchisor and the franchisee to retain the information confidentially (the CFL, Art. 11). This can be understood, especially in the case of the franchisors who spend a large quantity of money on establishing a franchise; thus, it is unsurprising that they wish to protect confidential matters (see Appendix 2).

\subsection{Are there Exemptions from Disclosure?}

Despite the centrality of disclosure in franchising, some franchise legislations do provide for franchisor-friendly disclosure exemptions (Bailey \& Wieczorek, 2014: p. 97-98). The disclosure exemptions provided for, in, for example, the U.S. (FTC Rule 16. C.F.R. $\$ 436.8$ ) and UNIDROIT Model (the UNIDROIT, Art. 5). Some of the considerable grounds for disclosure exemption are: 1) the case of the franchise sales to officers, directors, general partners and managers (collectively, "insiders") of a franchisor (U.S. FTC Rule 16. C.F.R. $₫ 436.8(\mathrm{a})(6)$; the UNIDROIT, Art. 5(A)). This seems to be logical, since the franchisee has been involved with the franchise and is in less need of disclosure. 2) In a case where the franchise is granted to a large franchise investment (for example U.S. FTC Rule 16 C.F.R. $\$ 436.8(\mathrm{a})(5)(\mathrm{i})$; the UNIDROIT, Art. 5(E)). The justification for this rests upon the assumption that a franchisee making a large franchise investment will be more sophisticated, and so is less likely to require the protection afforded by the disclosure law. 3) In the case of the renewal or extension of a franchise under the same conditions as previously (for example the UNIDROIT Art. 5(F)). This is because the relationship ongoing, and the franchisee therefore has all the information he needs as he is already committed to the relationship, and so there is no need for disclosure.

In Saudi Arabia, there are no comparable provisions addressing disclosure exemptions under the CFL. However, it would be useful within the franchising environment in Saudi Arabia to exempt some types of transactions to save time, and reduce effort and costs. To do so, would be to encourage the franchising sector. In other words, the less commitments and complications affecting the franchisor the more encouragement for franchising. Therefore, the aforementioned examples related to exemptions can exist alongside others where appropriate, and adopted under the CFL, as long as they are based on reasonable justifications.

\subsection{The Consequence of Franchise Disclosure Non-Compliance}

On some occasions the franchisor may not comply with the obligation to make a franchise disclosure, in such circumstances, a question arises as to the law's response.

According to the CFL in such cases, the franchisee shall have the right to terminate the franchise agreement-by a writing notice to the franchisor-without 
the franchisor being compensated (the CFL, Art. 17), provided that the entitlement of termination occurs before one year has elapsed since the franchisee became aware of the franchisor's non-compliance, or before three years has elapsed since the date of occurrence of the non-compliance, whichever is earlier. If the franchisee chooses to terminate the contract, the franchisor is obliged, upon the franchisee's request, to repurchase the assets used exclusively for the franchising business that the franchisee had purchased from him or someone else based on his instructions (the CFL, Art. 20). Upon the franchisor's non-compliance the franchisee has the right to sue for damages incurred by him, regardless of the termination of the franchise agreement (the CFL Art. 19). Additional to the aforementioned remedies, an administrative penalty can be imposed on the franchisor by the Ministry of Commerce not exceeding (SR500,000) (the CFL, Art. 24(1)), with the possibility of the sanction of a public announcement at the expense of the franchisor (the CFL, Art. 24(5)). These statutory remedies are in line with other franchise laws internationally (see the UNIDROIT; the ACCC). In U.S. the FTC Rule does not provide for a private right of action but provides for one at state level (Sellinger $v$ Freeway Mobile Home Sale).

Other jurisdictions go further in imposing additional remedies in their franchise statutes, such as the imprisonment (the Malaysian Franchise Act, section 39(1)(b)), prohibition from entering into any new franchise agreements or from appointing any new franchisees (the Malaysian Franchise Act, section 39(2)). Nevertheless, the Saudi legislator adds a layer of legal protection favouring the franchisee, in a relationship often dominated by the franchisor.

\section{Conclusion}

\subsection{Notable Finding}

After the exploring and analysing of the pre-contractual disclosure as a mandatory element imposed by the CFL, it is important to highlight some notable findings:

- With the introduction of the CFL, Saudi Arabia entered a new arena in the world of franchising, making it a destination for international companies because of its robust economy and the existence of a clear legal environment.

- The CFL was introduced to cure a critical issue, the franchise disclosure, that had always been in a legislative vacuum, as there were no clear legal grounds obliging franchisors to provide a franchise disclosure.

- This study reveals that despite the requirement of disclosure as an essential aspect of franchise law, it is not sufficient, on its own, to create a healthy legal environment for a franchise market. Rather, this disclosure must be accompanied by "relationship provisions" that address the ongoing relationship between the contracting parties.

- The disclosure as introduced by the CFL, including its embodied requirements, is compatible with most franchising practices around the world.

- The amount of information to be disclosed to the CFL is not onerous to the 
extent that it harms franchise transactions. Rather, it is a reasonable exchange of information that maintains the balance between providing the franchisee with the necessary information and maintaining the privacy and business secrets of the franchisor.

- Despite the reasonable franchise requirements and the way that it should be implemented, the disclosure could have been more accurate if the franchisor was required to provide as "acknowledgment receipt" of disclosure documents. It would also have had been improved if "disclosure exemption" had been incorporated within the CFL for ease of franchise activities.

\subsection{Summary}

For prospective investors, franchising represents a successful means of doing business in Saudi Arabia. This is evidenced by the fact that Saudi Arabia has acquired around $50 \%$ of the market value of the franchises in the Middle East and North Africa region, with an approximate value of U.S. 30 billion dollars. As such, the franchisor-franchisee relationship is highly significant from a legal perspective, because the potential franchisee requests disclosure information from the franchisor and relies upon the accuracy and comprehensive of such information. Almost four decades after the first franchise activity in Saudi Arabia, the new Commercial Franchise Legislation finally came to the light. The legislation provides a healthy regulatory environment, in particular spelling out with precision what a franchisor must include in disclosure documents prepared for prospective franchisees.

The requirement of disclosure as introduced by the CFL adds a layer of legal protection which favours the franchisee, in a relationship often dominated by one-sided franchise agreements where the franchisee is in an unequal bargaining position with a franchisor offering its established business model. This disclosure, according to the legislative provisions, must be accurate, timely, and verified, to enable the prospective franchisee to make an informed decision. In addition, disclosure is not enough in itself to create legal protection for the franchisee as the weak party in a franchise agreement. It is the combination of relationship law and disclosure law which can, to a large extent, improve the balance of power between the franchisee and the franchisor. In general, the requirement of pre-contractual disclosure, as it is introduced by the Saudi legislator, is inconsistent with the majority of national franchise legislations in countries that have introduced franchise specific-legislations. The Saudi legislator by issuing the new franchise legislation is announcing the entrance into a new era of franchising.

\section{Acknowledgements}

The author would like to express his sincere gratitude to Dr. Faisal Alfadel who gave generously of his time and knowledge in the preparation of this paper. 


\section{Conflicts of Interest}

The author declares no conflicts of interest regarding the publication of this paper.

\section{References}

Abell, M. (2011a). The Regulation of Franchising around the World. International Journal of Franchising Law, 9, 3-20.

Abell, M. (2011b). The Regulation of Franchising in the European Union. Ph.D. Dissertation, London: Queen Mary Univ.

Alghamdi, A. M. (2015). The Complexities of Franchise in Saudi Arabia an Analytical and Critical Study. King Abdulaziz University S.P.C, 29, 273-317. https://doi.org/10.4197/Eco.29-1.7

Al-Jabar, M. (1997). Commercial Contracts and the Banking Transactions. Riyadh: King Saud University.

Bailey, J. M., \& Wieczorek, D. E. (2014). Franchise Disclosure Issues. In R. M. Barkoff, \& A. C. Selden (Eds.), Fundamentals of Franchising (pp. 95-132). Chicago, IL: American Bar Association, U.S.

Blair, R. D., \& Lafontaine, F. (2005). The Economics of Franchising. Cambridge: Cambridge University Press. https://doi.org/10.1017/CBO9780511753879

Brickley, J. A. et al. (1991). The Economic Effects of Franchise Termination Law. The Journal of Law and Economics, 34, 101-132. https://doi.org/10.1086/467220

Brown, H. et al. (2014). Franchising: Realities and Remedies. New York: Law Journal Seminars Press, U.S.

Burns, J. G. (2013). Introduction to Islamic Law: Principles of Civil, Criminal, and International Law under the Shari'a. London: Teller Books, U.K.

Cahn, D. L., \& Woods, W. K. (2001). Item 19 Earnings Claims-A Disclosure Most Franchisors Should Try to Make. Franchise Law Journal, 20, 122-131.

Campbell, D., \& Netzer, A. (2008). International Franchising. Groningen: Kluwer Law Int'l.

Dicke, T. S. (1992). Franchising in America: The Development of a Business Method, 1840-1980. North Carolina, NC: UNC Press.

Emerson, R. W. (1990). Franchising and the Collective Rights of Franchisees. Vanderbilt Law Review, 43, 1503-1567.

Emerson, R. W. (2012). Are Franchisees Well-Informed: Revising the Debate over Franchise Relationship Laws. Albany Law Review, 76, 193-216. https://doi.org/10.2139/ssrn.1985718

Emerson, R. W. (2016). Franchise Savoir Faire. Tulane Law Review, 90, 589-646.

Eydt, G. J. (2013). The Devil Is in the Details: How Canadian and U.S. Franchise Legislation Differs. Franchise Law Journal, 32, 237-246.

Fisher, L., \& Mullin, C. L. (2000). Franchise Law in an Age of Electronic Communication. Franchise Law Journal, 19, 47-51.

Forgas, B. et al. (2017). Should International Disclosure Documents Be the Norm or Best Practice for International Franchise Transactions. International Journal of Franchising Law, 15, 19-34.

Gandhi, H. V. (2014). Franchising in the United States. Law and Business Review of the Americas, 20, 3-24.

Germann, S., \& Christie, A. (2010). Franchising: To Regulate or Not to Regulate? Interna- 
tional Journal of Franchising Law, 8, 11-35.

Hadfield, G. K. (1990). Problematic Relations: Franchising and the Law of Incomplete Contracts. Stanford Law Review, 42, 927-992. https://doi.org/10.2307/1228908

Hadfield, G. K. (1990). Problematic Relations: Franchising and the Law of Incomplete Contracts. Stanford Law Review, 42, 927-992.

Hillstrom, L. C. (2017). Encyclopedia of Small Business. Farmington Hills, MI: Gale.

Horwitz, D. P., \& Volpi, W. M. (1980). Regulating the Franchise Relationship. St. John's Law Review, 54, 217-278.

Jones, P., \& Wulff, E. (2007). Franchise Regulation in China: Law, Regulations, and Guidelines. Franchise Law Journal, 27, 57-62.

Killion, W. L. (2008). The Modern Myth of the Vulnerable Franchisee: The Case for a More Balanced View of the Franchisor-Franchisee Relationship. Franchise Law Journal, 28, 23-33.

Lagarias, P. C., \& Boulter, R. S. (2010). The Modern Reality of the Controlling Franchisor: The Case for More, Not Less, Franchisee Protection. Franchise Law Journal, 29, 1-10.

Lagarias, P. C., \& Kushell, E. (2013). Fair Franchise Agreements from the Franchisee Perspective. Franchise Law Journal, 33, 3-31.

Luxenberg, S. (1985). Roadside Empires: How the Chains Franchised America. New York: Viking.

Morrison, K. A. (1996). An Empirical Test of a Model of Franchisee Job Satisfaction. Journal of Small Business Management, 34, 27-42.

Peters, L. (2004). Franchising: Recent Legislation and the UNIDROIT Model Franchise Disclosure Law. Business Law International, 5, 33-66.

Peters, L. (2015). Genesis of a Model Law: The Unidroit Model Franchise Disclosure Law and Its Sources of Inspiration. Uniform Law Review, 20, 81-115.

https://doi.org/10.1093/ulr/unv003

Peterson, A., \& Dant, R. P. (1990). Perceived Advantages of the Franchise Option from the Franchisee Perspective: Empirical Insights from a Service Franchisee. Journal of Small Business Management, 28, 46-61.

Pitegoff, T. M., \& Garner, W. M. (1989). Franchise Relationship Laws: A Minefield for Franchisors. Business Law, 45, 183-225.

Pruitt, M. (1985). Disclosure and Good Cause Legislation: Where's the Beef in Franchise Regulation. Commercial Law Journal, 90, 563-570.

Ribstein, L. E. (1993). Choosing Law by Contract. Journal of Corporation Law, 18, 245-300.

Sherman, A. J. (2003). Franchising and Licensing: Two Powerful Ways to Grow Your Business in Any Economy.

Sotos, J. (2012). Recent Trend in Franchise Regulation Law. International Journal of Franchising Law, 10, 3-28.

Spencer, E. C. (2009). Consequences of the Interaction of Standard Form and Relational Contracting in Franchising. Franchise Law Journal, 29, 31-39.

Stanworth, J., \& Curran, J. (1999). Colas, Burgers, Shakes and Shirkers: Towards a Sociological Model of Franchising in the Market Economy. Journal of Business Venturing, 14, 323-344. https://doi.org/10.1016/S0883-9026(98)00019-6

Statement of Basis and Purpose (1978). Statement of Basis and Purpose Relating to Disclosure Requirements and Prohibitions Concerning Franchising and Business Opportunity Ventures, 43 Fed. Reg. 59, 623. 
The Commentary on the Provisions of the UNIDROIT.

https://www.unidroit.org/instruments/franchising/model-law

The Economic Journal of the Eastern Chamber of Commerce in Saudi Arabia (2017). Issue No. 536.

http://web.chamber.org.sa/3d/iktisad/issues/536/html5/index.html?page=1\&noflash

The Saudi Franchise Expo, Which Was Hold on 15-17 April 2020 on Riyadh. http://www.saudifranchiseexpo.com/about.php\#saudi-franchise-market

Vanderbroek, M. S., \& Turner, C. B. (2006). Protecting and Enforcing Franchise Trade Secrets. Franchise Law Journal, 25, 191-204.

Vogel, F. (2000). Islamic Law and Legal System: Studies of Saudi Arabia. Leiden: Brill.

Watson, A., \& Stanworth, J. (2006). Franchising and Intellectual Capital: A Franchisee's Perspective. International Entrepreneurship and Management Journal, 2, 337-349. https://doi.org/10.1007/s11365-006-0005-0

Wulff, E. B. (2005). International Franchising. International Law, 39, 325-332.

Young, J. (2011). Recent Development in Franchising in the Middle East and North Africa. International Journal of Franchising Law, 9, 9-14.

\section{U.S. Cases:}

Bresler's 33 Flavors Franchising Corp. v. Wokosi, 591 F. Supp. 1533 (E.D. Wis. 1984).

Designs in Medicine, Ic. v. Xomed, Inc., 522 F. Supp. 1054, 1058 (E.D. Wis. 1981).

Kubis \& Perszyk Assocs. Inc. v. Sun Microsys Inc., 680 A.2d 618 (N.J. 1996).

Neptune T.V. \& App. v. Litton Microwave, Etc., 190 N.J. Super. 153 (N.J. Super. A.D. 1983)

Seaway Yachts, Inc. v. Brunswick Corp., 242 So. 2d 192 (Fla. 3d D.C.A. 1970).

Sellinger v Freeway Mobile Home Sale, Inc., 521 P.2d 111 (Ariz. 1974).

Shell Oil Company v. Marinello, 307 A.2d 598, 601-02 (1973).

Susser v. Carvel Corp., 206 F. Supp. 636, 640 (S.D.N.Y. 1962), 332, F2d 505 (2d Cir. 1964).

Ticknor v. Choice Hotels Int' I Inc., 265 F.3d 931 (9th Cir. 2001).

\section{Website:}

The European Franchise Federation (EFF) Website. http://www.eff-franchise.com/101/franchising-definition-description.html

The Federation Française de la Franchise (FFF) Website. https://www.franchise-fff.com/franchise

The International Franchise Association (IFA) Website. https://www.franchise.org

The Saudi Franchise Expo, 15-17 April 2020 on Riyadh Website. http://www.saudifranchiseexpo.com/about.php\#saudi-franchise-market 


\section{Appendixes}

(Appendix 1): Table constitutes the most features and controversial items under the disclosure in the franchise laws. The selection of countries takes into account jurisdictional and geographical variations.

\begin{tabular}{|c|c|c|c|c|c|c|c|}
\hline Bankruptcy history & $\checkmark$ & $x$ & $\checkmark$ & $\checkmark$ & $x$ & $\checkmark$ & $\checkmark$ \\
\hline Franchisor's financial position & $\checkmark$ & $\checkmark$ & $\checkmark$ & $\checkmark$ & $\checkmark$ & $\checkmark$ & $\checkmark$ \\
\hline Supplies of goods and service & $\checkmark$ & $x$ & $\checkmark$ & $\checkmark$ & $\checkmark$ & $\checkmark$ & $\checkmark$ \\
\hline Initial and on-going fees & $\checkmark$ & $x$ & $\checkmark$ & $\checkmark$ & $\checkmark$ & $\checkmark$ & $\checkmark$ \\
\hline Market analysis & $x$ & $\checkmark$ & $x$ & $x$ & $x$ & $x$ & $x$ \\
\hline Ongoing relation terms. ${ }^{1}$ & $\checkmark$ & $\checkmark$ & $x$ & $x$ & $\checkmark$ & $\checkmark$ & $x$ \\
\hline Litigation history & $\checkmark$ & $x$ & $\checkmark$ & $\checkmark$ & $x$ & $\checkmark$ & $\checkmark$ \\
\hline Earning claims. & $\mathrm{O}$ & $x$ & $\sqrt{ }^{2}$ & $\mathrm{O}$ & $x$ & $\mathrm{O}$ & $\mathrm{O}$ \\
\hline Franchise network. ${ }^{3}$ & $\checkmark$ & $\checkmark$ & $\checkmark$ & $\checkmark$ & $x$ & $\checkmark$ & $\checkmark$ \\
\hline Secrets of the business format & $x$ & $x$ & $x$ & $x$ & $x$ & $x$ & $x$ \\
\hline \multirow[t]{2}{*}{ Intellectual property ${ }^{4}$} & $\checkmark$ & $\checkmark$ & $\checkmark$ & $\checkmark$ & $\checkmark$ & $\checkmark$ & $\checkmark$ \\
\hline & U.S. & France & China & Australia & Malaysia $^{5}$ & UNIDROIT & Saudi Arabia \\
\hline
\end{tabular}

Required: $(\checkmark)$ Not required: $(\boldsymbol{X})$ Optional: $(\mathbf{O}) .{ }^{1}$ This primarily concerns issue such as renewal, termination, transfer and dispute resolution. ${ }^{2}$ Art. $22(8)$ requires the business status of existing franchisees, and business status means the existing franchisees' investment amount, average sales turnover, gross profit and so on. Measures for Administration on Information Disclosure of Commercial Franchises 2007 (Information Disclosure Measures). ${ }^{3}$ This includes information about the existence of the "networks" outlets, the "chain" of franchisees, and the name and address of each franchisee in the network. ${ }^{4}$ This includes (trade name, trade name, logo, ...etc.). ${ }^{5}$ The Malaysian Franchise Act imposes the obligation of disclosure, but it does not list what must be disclosed, although much of the information that must be in the franchise agreement by law overlaps with the information to be disclosed. The disclosed items are found in the Code of Ethics that introduced by the Malaysian Franchise Association (MFA).

(Appendix 2): (Table comprises the most common feature and controversial procedures and requirements of disclosure under franchise laws. The selection of countries takes into account jurisdictional and geographical variation):

\begin{tabular}{|c|c|c|c|c|c|c|c|}
\hline Exemption from disclosure & $\checkmark$ & $x$ & $x$ & $x$ & $x$ & $\checkmark$ & $x$ \\
\hline Post-contracting registration of disclosure & $x^{1}$ & $x$ & $\checkmark$ & $x$ & $x$ & $x$ & $\checkmark$ \\
\hline Pre-contracting registration of disclosure & $x$ & $x$ & $x$ & $x$ & $\checkmark$ & $x$ & $x$ \\
\hline Confidential information protection & $x$ & $x$ & $\mathrm{O}$ & $\mathrm{O}$ & $\checkmark$ & $x$ & $x$ \\
\hline Disclosure recipient acknowledgment & $\checkmark$ & $x$ & $\checkmark$ & $\checkmark$ & $x$ & $x$ & $\checkmark$ \\
\hline Cooling-off period & $x$ & $x$ & $\checkmark$ & $\checkmark$ & $\checkmark$ & $x$ & $x$ \\
\hline \multirow[t]{2}{*}{ Timing of disclosure ${ }^{2}$} & 14 & 20 & 30 & 14 & 10 & 14 & 14 \\
\hline & U.S. & France & China & Australia & Malaysia & UNIDROIT & Saudi Arabia \\
\hline
\end{tabular}

Required: $(\checkmark)$ Not required: $(\boldsymbol{X})$ Optional: $(\mathbf{O}){ }^{1}$ The FTC Rule does not impose a federal registration obligation. However, this is required by some states, which typically require a pre-offer review and approval process for a registration application. These states are: California, Hawaii, Illinois, Indiana, Maryland, Michigan, Minnesota, New York, North Dakota, Rhode Island, South Dakota, Virginia, and Washington. ${ }^{2}$ In days. 